\title{
東京におけるイベントの力とその将来性
}

\author{
東秀紀* \\ The Implications and Possibilities of Big Events in Tokyo
}

Hideki AZUMA*

[Received 10 April, 2012; Accepted 17 March, 2014]

\begin{abstract}
Urban planning and big events, such as the Olympic Games and Universal Expositions, are complementary. Big events promote urban planning, and often cause it to evolve. Urban development by Napoleon III and successive Universal Expositions led Paris to become a fashionable global center. The 2012 Summer Olympic and Paralympic Games in London contributed to gentrifying the London Docklands and the neighboring East End. The 1964 Summer Olympic Games in Tokyo also led to modernization of urban infrastructures and celebrated Japan's revitalization and progress after the Second World War. However, the 1964 Olympic Games left some bad legacies, including damage to the historical landscape around Nihon-bashi bridge by an expressway. Now, as we prepare to hold the 2020 Summer Olympic and Paralympic Games in Tokyo, we should think not only about the events but also urban planning at the Tokyo Waterfront, where the main facilities are to be built. This paper presents the relationship of between urban planning and big events in modern history, and discusses implications and possibilities.
\end{abstract}

Key words : Tokyo, Olympic Games, event, world expositions, urban planning キーワード：東京，オリンピック，イベント，万国博覧会，都市計画

\section{I. 都市計画と大規模イベント}

\section{1) 本論文の目的と構成}

本論文の目的は, 19 世紀から 21 世紀に至る近 代および現代都市計画に，万国博覧会（以下，場 合により万博と略す)，オリンピック（2001 年国 際オリンピック委員会・国際パラリンピック委員 会の連携合意後はオリンピック・パラリンピッ ク）などの大規模イベントが，どのような影響を 及ぼしてきたかを，1964 年夏季東京オリンピッ クを中心に考察し，2020 年夏季に再び行われる 東京オリンピック・パラリンピックヘ向けて留意 点を指摘することにある。
論文の構成は以下の形をとる。

I. 都市計画と大規模イベント

1）本論文の目的と構成

2）近代都市計画の起源

II. 海外の事例
1) パリ
2) ロンドン

III. 東京オリンピック 1964

1）招致までの経緯

2) 東京オリンピックと都市計画

3）オリンピックの成果と課題

IV. 今後の東京計画と大規模イベント

1） 2 回の挫折

* 首都大学東京大学院都市環境科学研究科

* Graduate School of Urban Environmental Science, Tokyo Metropolitan University, Hachioji, 192-0397, Japan 
2）2020 東京オリンピック・パラリンピック へ向けて

「I. 都市計画と大規模イベント」では，本論文 を書く狙いと, 章構成について説明し, 都市計画 と大規模イベント（万博, オリンピックなど） と が，相互補完の関係にあることを述べる。

「II. 海外の事例」においては，明治以降，東京 の都市計画に大きな影響を与えてきたロンドンと パリが大規模イベントと関係しあいながら，都市 計画を進めてきた経過を紹介する。具体的には, パリではオスマンの都市改造と万国博覧会, ロン ドンではドックランズ開発と 2012 年に開催され たオリンピック・パラリンピックをとりあげる。

「III. 東京オリンピック 1964」では，1964 年 夏季オリンピックの開催と戦後東京の都市計画と の関係を，道路，公園，建築など基盤整備を中心 に述べ，当時顕在化しつつあった都市問題の解決 にオリンピックが大きく貢献したこと, 同時に負 の面も残したことを指摘する。

$\lceil I V$. 今後の東京計画と大規模イベント」では, 20 世紀末から 21 世紀初期に構想された 2 つの大 規模イベント（世界都市博覧会と 2016 年夏季才 リンピック・パラリンピック誘致）が構想段階で 挫折した理由を探り,さらに開催の決定した 2020 年夏季オリンピック・パラリンピックへの留意点 を述べる。

\section{2）近代都市計画の起源}

近代都市計画は 19 世紀の 100 年間に，ロンド ンの人口が 70 万から 400 万以上，パリの人口が 50 万から 200 万以上へと増大するなど，欧米に おける大都市の誕生に起源をもつ（Hall, 1988）。

大都市誕生の主たる原因となったのは産業革命 による都市への人口集中，またロンドン，パリで は欧米列強の植民地を求めての海外進出による首 都への富の集中であった。

西欧において，100万を越える都市があらわれ たのは古代ローマ以来であり, その登場は長短両 面の効果をもたらした。

長所の第一は経済的繁栄である。産業革命で 潤った富が欧米先進国にもたらされ，とくに英仏 両国のアジア，アフリカへの海外進出は，首都で
あったロンドンとパリを世界的大都市へと変えた。 たとえばイギリスは 19 世紀に「世界の工場から 世界の銀行・手形交換所へ」（秋田, 2012）と変貌 を遂げるが，これによってもたらされた富をもっ とも享受した都市も首都ロンドンであった。

長所の第二は文化的爛熟である。物質的豊かさ は社会の支配者となったブルジョワ層に消費と娛 楽の楽しみをあたえ, 欲望を刺激する起爆剤とし て, ファッション，ポスター，写真など，ヴァル ター・ベンヤミンのいう「高度複製芸術」の登場 をもたらした。この結果, パリは「花の都」とし て，フランス一国のみならず，世界のファッショ ン・センターの位置を確立した。

もっとも，人口集中は必ずしもよい効果だけを もたらしたわけではない。ロンドンもパリも 19 世紀初頭は中世都市以来の姿を残したままで，道 路, 上下水，住宅など都市基盤の整備は大きく遅 れていたからである。

たとえば，19世紀のロンドン，パリでは地下 鉄があらわれるまで，都市の公共交通は馬車に限 られ，道路は慢性的な渋滞に悩まされていた。

さらに深刻だったのは人口過密による衛生問題 である。排泄物を道路に捨てる中世以来の習慣は, 19 世紀前半にロンドンやパリでコレラなど疫病が 流行する原因となった。貧民の多くが住むロンドン 東部のスラムでは住宅の過密がとくにひどく，その 悲惨な状況は，フリードリヒ・エンゲルス『イギ リスにおける労働者階級の状態』などに報告され ている。また，大都市に扔ける社会的不平等とス ラムの発生は社会不安をも生み, ロンドンのイー スト・エンドでは「切り裂きジャック」などの殺 人事件が頻発し，パリでは革命や騒乱が起きる原 因となった（喜安・川北, 1986）。

大都市の長所を伸ばし，短所を解決する方策と して，もっとも早く近代都市計画が着手されたの もロンドンとパリの 2 都市である。ロンドンでは 19 世紀末に田園都市構想があらわれ，第二次世 界大戦後の大ロンドン計画，そして 20 世紀末の ドックランズでのウォーターフロント開発へと続く。 また，パリでは，ナポレオン III世の指揮のもと， セーヌ県知事オスマンによってはじめられた都市 
改造が 19 世紀半ばから約半世紀をかけて行われ た。これら 2 都市の都市計画は, わが国近現代の 都市計画に（その出来上がりは当初の夢と大きく 違ったとはいえ）影響をあたえた。具体的には才 スマンのパリ改造が明治の市区改正計画に，大口 ンドン計画が戦後の首都圈整備計画に対してと いった影響である（石田, 2004）。

パリとロンドンで都市計画と並行的に行われた のが，万国博覧会，近代オリンピックなどの大規 模イベントであった。参加する団体や人が世界的 な規模をもち，開催できる都市は限られ，大々的 な施設整備も必要なことから, 都市計画と大きく 関わった。

パリ，ロンドンの 2 都市は都市計画のみならず， 万国博覧会，オリンピックの開催についても先駆 的役割を果たした。ロンドンは史上初の万国博覧 会を 1851 年に開催し，オリンピックでは過去 3 度という最多の開催回数を誇っている。また，パ リも万国博覧会の実績では 1855 年から 1937 年ま で，ほほ 10 年に 1 度の割合で博覧会を開催しつ づけ，博覧会国際事務局の一般博覧会リストに記 載されている開催数 7 回は世界最多と群を抜く。

以上から，本論文は都市計画と大規模イベント が深いつながりをもつとし, 産業革命をもっとも 早く経験することで近代都市計画を先導し，大規 模イベント開催の実績を多くもつパリとロンドン の 2 都市について検証する。さらに, 1964 年東 京オリンピックも同様に考察し, 最後に 2020 年 開催の決まった東京オリンピック・パラリンピッ クを行うにあたり，考慮すべき点を指摘する。

\section{II. 海外の事例}

\section{1) パリ}

万国博覧会の第 1 回は，1851 年ロンドンにおい て開かれた国際博覧会（Great Exhibition）とさ れるが，現在の万国博覧会を意味する Exposition universelle（英訳 Universal Exposition）という 名称になったのは第 3 回パリ博覧会（1855）以降 である（鹿島, 1992）。

その 2 年前, ナポレオン III 世がジョルジュ・ オスマンをセーヌ県知事に任命して，パリ改造の
着手を命じており，都市計画とイベントとは，ほ ぼ同時期に構想されたといってよい。

オスマンの都市改造の中心は都心に幹線道路を 整備することであった。交通渋滞を引き起こしてい た中世以来の曲がりくねつた道路を広い直線道路 に拡大し，セーヌ両岸にかかる橋を増設して，道 路交通体系をより効率的にしょうとしたのである。

道路を広くするだけでなく，幹線道路の両脇を 並木道とし，建築は高さと様式など外観を揃える よう規制を設けて，美しく見晴らしのいい街並み 景観を現出させたのも，オスマンによる都市改造 の成果である。幹線道路は放射線状に広がり, 道 路が集中する広場にはオペラ座のような美しい建 築や凱旋門，銅像やオベリスクの記念碑などがラ ンドマークとして置かれた。ランドマークのなか には，長年の度重なる修理で損なわれていた外観 を建設当時のゴシック様式に復元し，周囲の密集 市街地を整備して空地をつくりだしたノートルダ ム寺院などの例もある。

このほか，オスマンの都市改造は公園整備，上 下水道整備など，広い範囲に及び，現在のパリ都 心の過半をつくって，今日に至っている。

この都市改造の成果を各国の人々が目の当たり にしたのが，パリにとって 2 度目の開催となった 1867 年万国博覧会である。このときの博覧会は, 1855 年のものよりもナポレオン III 世の意思を反 映したといわれ，各国の皇帝や国王から一般の団 体客までがパリに押し寄せた。そこで彼らが目を 見張ったのが，街並み，道路，建築といったパリ という都市の壮麗さだったのである。

ロシア皇帝アレクサンドル II 世はパリみやげと して，ナポレオン III 世に都市計画図を所望した し，このあとべルリンやブリュッセルなどヨーロッ パ各国の首都では，パリに範をとった都市改造の 䤼音が響く。日本からも徳川幕府，薩摩藩が万博 に出展し，渋沢栄一など派遣団に加わっていた 人々は明治になってから, 近代日本の首都東京の 都市計画の範をパリに求めた（藤森, 1982）。

ナポレオン III 世の退位後もパリ改造が続けら れたのは都市改造の必要性がパリ市民によって認 識されていたからであり，そこに万博の寄与が 
あったことはいうまでもない。実際ナポレオン III 世の帝政が終わった後も，20 世紀半ばまで， 2 つの世界大戦中を除く期間ほぼ 10 年に 1 度の 割合で万国博覧会は開催され続けられる。

そのときも博覧会の主役は会場内にとどまらず, パリという都市自体であり，1889 年万博で建設 されたエッフェル塔はパリの眺望で人気を集め, 1900 年と 1925 年の万博でパリ中を彩った建築や 地下鉄の駅は, アール・ヌーボー, アール・デコ などの様式として現代美術史を彩ることとなった。

オスマン時代には計画になかった地下鉄や建築 (グラン・パレ, プティ・パレ等), 構築物（アレ クサンドル III 世橋, エッフェル塔等) らも建設 され, 万国博覧会はパリ改造を進展させる役割を 担った。

いまわれわれが見る花の都パリとは，都市計画 とイベントが相互補完的に実行された成果にほか ならない。

\section{2) ロンドン}

パリがもっとも多く万国博覧会を開催した都市 であるとすれば，ロンドンはもっとも多くオリン ピックを開催した都市にあたる。2012 年開催を 入れて 3 度，第二次世界大戦中のため実際には 行われなかった 1943 年も含めれば 4 度一いずれ にしろ, 第 1 回開催地アテネを凌ぐ最多回数で ある。

もっとも初期 2 回のロンドン・オリンピックは, 現在のような華やかなイベントではなかった。1908 年（第 4 回）大会は，王女がウィンザー城の空か ら競技を見たいという希望にルートをあわせて，マ ラソンの距離が変更されるなどルールも未整備で あったが，このときの $42.195 \mathrm{~km}$ が正式な距離と して今日に至っているところをみると，かえって ロンドンという都市のオリンピックへの影響度を みることができる。1948 年（第 14 回）大会も第 二次世界大戦後はじめてのオリンピックで, 選手 の宿泊所には軍用施設や学校の寮などが使われ, 選手の食料も各国から持参することが奨励された が，大戦で荒廃したヨーロッパでオリンピックが 再開された地がやはりロンドンであったことの意 味は大きい。
しかし，過去と対照的に，64 年ぶりに行われた 2012 年オリンピック・パラリンピックはロンドン の大規模な都市計画と梁く結びつくこととなる。

大ロンドン市が国際オリンピック委員会（以下 IOC : International Olympic Committee の略) に提出した基本計画案では，主要施設は都心，ドッ クランズ，イースト・エンドの 3 地区に建設すると された。このうち大部分の施設が置かれるドックラ ンズとイースト・エンドの 2 地区は隣接しており, 実際にはロンドン東部として, 地理的には一体に考 えてよい地域であった。

ドックランズは 1980 年代初頭に再開発プロジェ クトが開始された旧港湾地区である。当時のサッ チャー政権主導により，都心部とモノ・レールで 結ばれたカナリー・ウォーフに現出した超高層ビ ル群の景観は, 同時期に行われた東京湾臨海部開 発のモデルとなったことで有名である（東, 2004）。

しかし，そのドックランズの巨大開発もバブルが はじけ，牽引車だったカナダの民間デベロッパー， オリンピア・アンド・ヨーク社が倒産した 1990 年 代，大きく行き詰まった。さらに，古くから貧民街 として知られた隣接のイースト・エンドが, サッ チャー政権の下でドックランズと対照的に放置され たままだったのも問題であった。

20 世紀末，約 20 年ぶりに政権を回復した労働 党のトニー・ブレア政権は, 中央政府の管轄下に あった開発公社を解散するとともに，ドックラン ズに関する権限を大幅に地方自治体に移管し, サッチャーによって廃止されていた大ロンドン市 を再発足させた。その結果労働党出身のケン・リ ビングストンが初代市長に当選し, 彼の下でつく られたのが，ドックランズとイースト・エンドを一 体化して考え，主要施設のほとんどをロンドン東 部に建設するというオリンピック・パラリンピック 計画案だったのである（住田, 2006; 馬場, 2007)。

ドックランズ開発計画では考慮されていなかっ たロンドン東部全体にわたる幹線道路, 地下鉄, 鉄道，空港，サイクリング道路などの交通基盤が 整備され，それまで富裕層向け中心だった住宅開 発も手ごろな価格で購入あるいは賃貸できる環境 共生型の住宅団地「イースト・ビレッジ・ロンド 
ン」をオリンピック選手村跡地に建設することと なった。

2000 年代になって, 政権・市政の双方は保守 党に奪還されるが，その都市政策は引き継がれ， オリンピック後も続いている。2012 年ロンドン のオリンピック・パラリンピック自体の成否につ いてはなお検証が必要としても，都市計画の面で いえば，長年の課題であったロンドン東部の更新 と活性化への意義は大きい。

パリが万国博覧会によって，華やかで文化的な 都市計画を実現したとすれば，ロンドンはオリン ピック・パラリンピックによって, 長年の懸案 だった東部地域を改善する都市計画への道筋を切 り開いたといってよいだろう。

\section{III. 東京オリンピック 1964}

\section{1）招致までの経緯}

前章において，パリ，ロンドンを例に都市計画 と大規模イベントとの関係について述べた。

では, 1964 年に開催された東京オリンピック は, どのように東京の都市計画と関連し，成果を あげたのだろうか。その問いに答える前に，まず 1964 年開催に至るまでの, 戦前, 戦後にわたる 30 年あまりの経緯をみてみよう。

\section{1-1)「幻のオリンピック」}

東京オリンピックは，実は戦前に 1 度開催が決 まっていながら，戦争によって中止のやむなきに 至った歴史をもっている。

オリンピック開催を発案したのは，1930（昭和 5）年当時の東京市長だった永田秀次郎といわれ る（東京市役所, 1939, p. 3)。10 年後の神武天皇 即位紀元二千六百年式典を機に関東大震災から復 興した東京の姿を世界に喧伝し，世界恐慌に巻き 込まれつつある日本の経済と社会をオリンピック で活性化させたいという狙いであった（橋本， 1994）。同じ 1940 年に東京万国博覧会も計画さ れていたことから，当時の日本人のイベントへの 期待がいかに大きかったかがうかがえる。

ローマ開催を目ざすムソリーニ説得にヒトラー の協力を得て, 1940 年東京での開催が決まり, 急ぎ会場案が練られた。そのとき東京にとって大
規模イベントを開催する可能性がある地として選 ばれたのが，臨海部，郊外という 2 つの可能性 である。

検討の結果, 臨海部の晴海埋立地を万博用地と し，郊外一具体的には神宮外苑，代々木，駒沢の 3 地区一をオリンピック主会場とし，とくにス ペースのとりやすい駒沢を中心としていくことと なった。そして神宮外苑から渋谷・代々木を経由 して駒沢に至る放射 4 号線の整備, ターミナル 駅として重要性を増す渋谷駅前広場開発などが計 画され, 浅草〜新橋の地下鉄と渋谷〜新橋の東京 高速鉄道の直通乗り入れが実現した。

だが，このオリンピックは1938（昭和 13）年, 万国博覧会とともに断念されてしまう。

日中戦争が激化するなかで，大規模イベントを 開催することに世論の支持が失われ，開催しても 英米仏などの参加が危うくなったからである。こ うしたなかで，明治維新以来，近代国家への道を 懸命に上っていた日本は，第二次世界大戦という 破滅への下り坂を転げ落ちていった。

\section{1-2）戦後の招致活動}

第二次世界大戦に敗れた日本が，戦後はじめて 参加したオリンピックは，1952（昭和 27）年の 第 15 回ヘルシンキ大会, 日本が独立を回復する サンフランシスコ平和条約締結の翌年である。こ の 1952 年 5 月に東京都議会で，かつてオリン ピックを返上して失われた「国際信義」を回復す るため，第 17 回オリンピック（1960 年）を招 致すべきであるという決議がなされている（片木， 2010)。当時の日本人たちが敗戦から立ち直ろう とするときに思い立ったのが，オリンピック再誘 致だったのである。

第 17 回開催の選挙は 1955（昭和 30）年パリ IOC 総会でローマに敗れたものの, 日本は次の 第 18 回（1964 年）開催に再挑戦する。そのた めに，まず 1958（昭和 33）年 IOC 総会を東京 に誘致した。委員たちに東京の復興を印象づけ, ちょうど開催中のアジア競技大会を見せて，日本 に大会運営能力があることを PR L， IOC 総会 中には，衆議院，参議院で「第 18 回オリンピッ ク大会東京招致決議案」を可決して，国と都との 
協力姿勢も示した。さらに翌 1959（昭和 34）年 5 月のミュンヘン IOC 総会では， 1 か月前の東京 都知事選挙で「オリンピック開催」を掲げて当選 したばかりの IOC 委員東 龍太郎が出席し，東京 が最多得票で開催を勝ちとった。それは日本がオ リンピック開催へ熱意をもっていることを世界に 訴えた成果であった。

戦前に関東大震災からの復興事業の総まとめと して発案された東京オリンピックは，戦争からの 復興をアピールして 29 年後に誘致成功まで，た どり着いたのである。

\section{2）東京オリンピックと都市計画}

第 18 回オリンピック大会東京開催が決まって, 1959（昭和 34）年 9 月 30 日日本では，組織委 員会が発足し，部会である施設特別委員会でオリ ンピック施設の基本計画が練られはじめた。

\section{2-1）道路整備事業}

戦前と同じく，神宮外苑，代々木，駒沢を主た る 3 会場とし, 神宮外苑では前年のアジア大会 で建設したばかりの国立競技場を利用，代々木に プールを含む国立屋内競技場，駒沢に第二競技 場，体育館を新たに建設することはすんなりと決 まったが，問題は選手村であった。

代々木地区は米軍の家族宿舎（当時「ワシント ン・ハイッ」と呼ばれていた）として接収されて おり，渋谷駅に近いこの便利な場所を，米軍が手 放す可能性は低い。そこで米軍駐屯地でも埼玉県 の朝霞基地なら返還の可能性があるだろうという 予測のもとに，選手村計画が立てられた。

しかし，選手村を朝霞に置くと，神宮外苑， 代々木，駒沢など主会場に行くのに，かなりの距 離がある。東京の自動車交通量は毎年増加し, 選 手たちの乗ったバスも渋滞に巻き込まれ，会場へ の到着も遅れかねない。また，海外からの旅行客 やマスコミ関係者たちに, 生まれ変わった東京を 見てもらいたいのに，羽田からホテルまでの道が 渋滞しては逆効果だ。こうして1964 年オリン ピック施設計画は, 道路交通が最大の課題と認識 された。

オリンピックまで，東京に道路計画がなかった わけではない。1927（昭和 2）年に制定された大
東京道路網計画では山の手地域を対象に放射・環 状の幹線街路がすでに都市計画決定されていた が，戦争のため，ほとんどが未着手だった。戦後 の復興計画でも，これら放射・環状の幹線街路計 画は復活し，オスマン開発後のパリにならって, 並木道をもつ「美観道路」として計画されたが, これも実際は手つかずのまま放置されていた (越沢, 1991)。

そうした道路問題を解決する手段こそ，まさに オリンピックの開催であった。当時東京都の建設 局都市計画部長だった山田正男は，1959（昭和 34）年夏，ヨーロッパに出張し，オリンピック 開催を 1 年後に控えたローマに立ち寄ったとき の衝撃をのちに「ローマをみてきて，なるほどオ リンピックを利用して都市を整備するのがオリン ピックだという事が分かったよ」（山田, 2001, p. 103）と語っている。

遺跡の上に現在の都市が建てられているローマ は，慢性的な交通啮滞に悩まされている。そのた め, 戦前から郊外に衛星都市群を建設し, それら を結ぶ高速道路計画があったが，第二次世界大戦 で中断していた。その道路計画がオリンピックを 機に復活し，工事が再開されているのだ。山田は 帰国後行った講演で，ローマがオリンピックを契 機に長年の課題であった道路整備を実現している ことを訴えた。

《ローマの都市計画もまた極めて日本的です。道 路の狭いこと，計画にバックボーンのないこと，局 部計画ばかり好きなこと。悪い所ばかり似ている のはどうしたものでしょう。但し，これは現状で す。[ローマでは］都市計画の樹立は着々として進 められており，自動車道路もどんどん建設されて います》(括弧補足は引用者。山田, 1960, p. 31)。

ローマと同様，オリンピックを利用すれば，東 京の都市計画で長く懸案となっている道路整備を 実現できるのではないか，と山田たち関係者は思 い至ったのである。

神宮外苑〜代々木〜駒沢の 3 会場をつなぐ放 射 4 号線（通称：青山通り，玉川通り）の拡幅， 選手村として想定している朝霞と 3 会場をつなぐ 環状 7 号線の新設など，高速，一般あわせて 22 


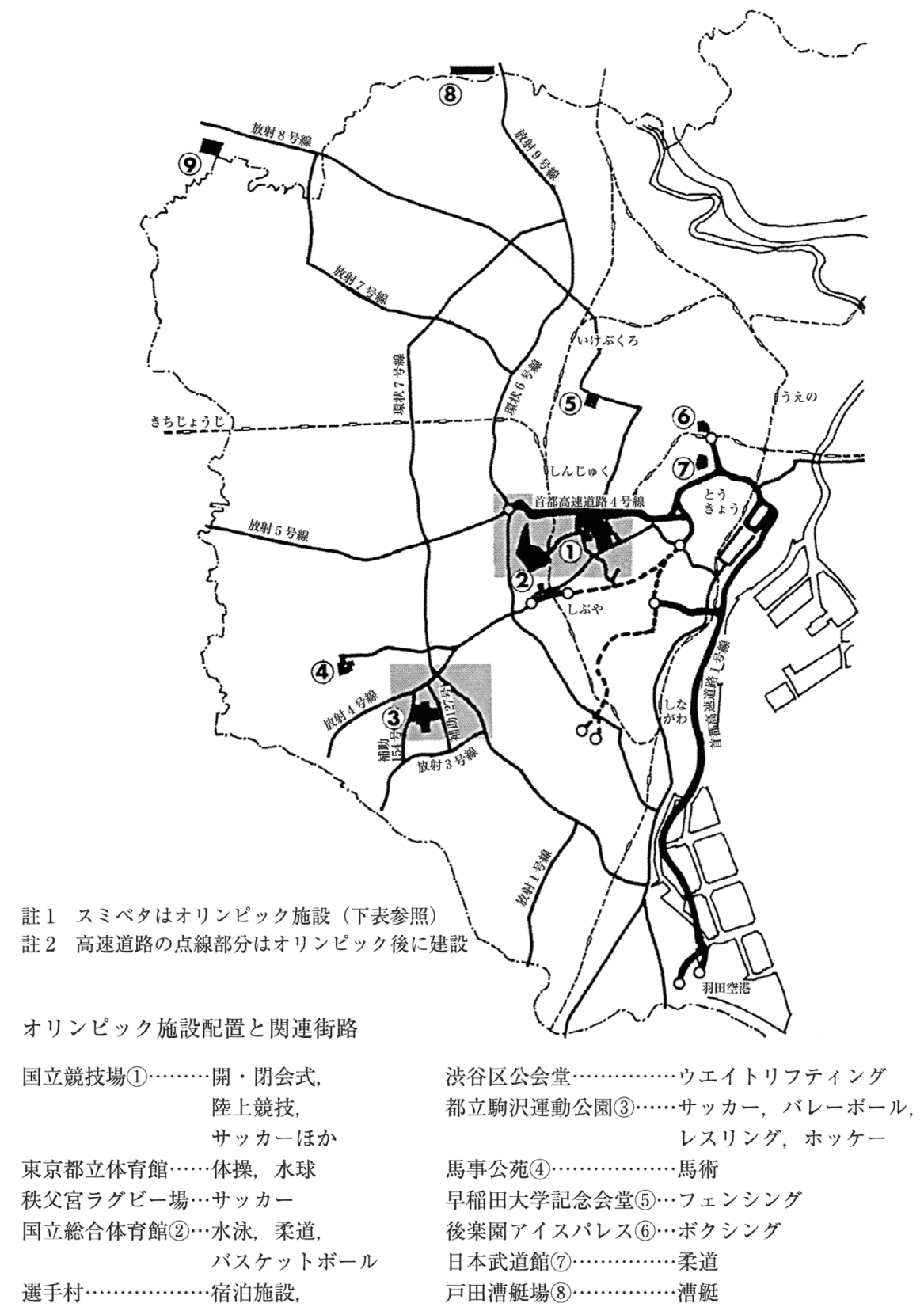

図 1 東京オリンピックにおける基盤整備（東, 2010, p. 256).

Fig. 1 Map of roads and fasclities for the 1964 Tokyo Olympic (Azuma, 2010, p. 256).

路線，総延長 $546 \mathrm{~km}$ に及ぶ道路が急遽実現され ていくこととなった（図 1)。

その代表的なものが, 環状 7 号線である。アメ
リカ側がワシントン・ハイツを返還した事情で朝 霞選手村案は中止になったが，ボート競技は戸田 漕艇場で行うことになったため，西半分（大田区 
平和島 6 丁目～足立区新田 2-2）は整備すること になった。この区間の整備にわずか 5 年しかかか らなかったのに比べ，残った東半分（足立区新田 2-2 江戸川区臨海町 6 丁目）の完成に，その後 20 年以上を要したことをみれば，道路工事の進渉 にオリンピックがいかに力を発揮したかがわかる。

だが，突貫工事はさまざまな問題を引き起こす。 たとえば，杉並区内の環状 7 号線沿いでは，1970 年代になって光化学スモッグが発生し, 放課後ク ラブ活動中の高校生が被害を受けた。また，用地 取得にかかる手間を省くため, 江戸以来の濠の上 に高速道路を通した, いわゆる「空中作戦」は, 日本橋付近の景観を大きく損なって, 現在に至っ ている。

21 世紀になり，オリンピック時に建設された高 架橋の大部分は, 想定をはるかに越える交通量と ともに，この空中作戦による急勾配が原因で，当 面の補修だけでは満足できない状況に達している （首都高速道路株式会社, 2013)。今や防災や耐震 政策を含め，東京の道路体系をどのように見直す か，道路や橋，トンネルをどのように補修し，つ くりなおすかは現在の東京の大きな課題となって いるのである。

\section{2-2）建築・公園整備}

前項で，オリンピック関連で整備された道路 が，今も東京の都市計画に大きな影響をあたえて いる事実を紹介した。本項では，建築や公園の整 備などを, 代々木, 駒沢の 2 地区について, 見 てみることとする。

\section{(1)代々木地区}

この地区はかつて陸軍の練兵場であったが, 戦 後米軍が住宅用地として接収し, その名もワシン トン・ハイッとして呼ばれていたことはすでに述 ベた。それがオリンピック開催にあたり，日本側 の予想を覆して返還されたのは，日米関係を重視 した新大統領ジョン・F・ケネディの決断であっ たといわれる（尾崎, 2002）。

返還された敷地には，丹下健三の設計する国立 屋内総合競技場をはじめ, 渋谷公会堂, NHK 放 送センター，そして選手村が建設された。このう ち，選手村のあった部分が現在の代々木公園にあ
たる。

国立屋内総合競技場は，丹下健三の名を世界に 知らしめた建築として今も有名である。丹下の設 計したすべての建築のなかでも，ダイナミックな 造形, 躍動感と比例美の点で最高の作品の 1 つで あろう（丹下・藤森, 2002）。東京オリンピック といえば，この屋内総合競技場を思い出す人は今 も少なくないほど，時代の記念碑となっている。

だが，代々木地区の難をいえば，丹下の名建築 は周囲に余裕がなく，公園とは道路によって分断 されている。これはワシントン・ハイツ敷地に, 屋内競技場と選手村だけでなく，NHK 放送セン ターや渋谷区公会堂が後から割り込んできたこと による（岸田ほか, 1963）。また，代々木公園は 別の造園家によって設計されたため，丹下の建築 との間に関係性が感じられない。不幸にも，代々 木地区はその建築の素晴らしさに匹敵する配置計 画をもつことができなかったのである。

\section{(2)駒沢地区}

逆に駒沢オリンピック記念公園（以下：駒沢公 園）では，建築と公園そして交通などの整合性が 計画の当初から意図されていたところが，代々木 地区と比べ対照的である。

駒沢公園も，戦前のオリンピック計画から主会 場として位置づけられ，1964 年オリンピックでも 主会場の 1 つとして整備された。戦時中は東京都 が買い上げて防災緑地, 終戦直後は食糧増産用の 農耕地として都民に貸し付けられていたが，昭和 20 年代後半になるとプロ野球球団がフランチャイ ズとする硬式野球場, 軟式野球場, バレーボール コート，弓道場などが雑多につくられ，一角には 木造の都営住宅などもあって, 敷地全体としても 不整形となり，土地利用も混在したまま放置されて いた。ここに既存の施設を撤去して，オリンピック ではサッカー，レスリング，バレーボール，ホッ ケーの 4 種目を行うために，第二陸上競技場，体 育館, 屋内球技場, 屋外球技コートなどが新設さ れることになったのである。よって施設ごとに異 なる建築事務所が定められたものの，全体をどう まとめるか，どこを敷地全体の正面とするのかな どが課題として残されていた。 
こうしたなかで，道路，建築，造園，都市計画 など異分野の関係者たちが協力しあい，調整して マスタープランをつくったところに駒沢の特徴が ある。

まず，オリンピックを考える前に，さまざまな スポーツ施設が点在し, 普通の人々が楽しめる総 合運動場公園にしょうという跡地構想が着手され た。そのときに早くも問題となったのが，駒沢地 区の玄関ともいうべき敷地正面をどことするかで ある。

敷地が不整形なこともあり, 41 ha という広さに 比へ，東側を通る補助 127 号線（自由通り），ある いは西側を通る補助 154 号線（駒沢公園通り）は, ともに公園に接する距離が短い。しかも，残る補 助 49 号線（駒沢通り）は幅員 $15 \mathrm{~m}$ と狭く, 敷地 を二分割してしまう。そこで補助 49 号線を幅員 $32 \mathrm{~m}$ の広い直線道路に改造し, 駒沢公園のバスス トップを設置した。さらにバスストップ部分を敷地 基盤より $5 \mathrm{~m}$ 低くして，その上に連絡橋を通し， 二分された敷地を一体化させた（高山・加藤, 1964)。

バスから降り立った来訪者たちは目の前の広い 階段を上っていけば，徐々に体育館，競技場など の建築が見えてきて，中央広場に誘い込まれる。 その中央広場には西洋の街のようにシンボルとし て塔を置き，床も舗装されている。駒沢公園の計 画では，道路中心でも，建築中心でもなく，総合 的な視点で専門家や管理者たちが知恵を出し合 い，協力しあったのである。

《僕は土木と建築と造園を総合化した都市計画 を担当した。その当時都市計画というと, 道路は 道路だけ，公園は公園だけというようにそれぞれ がばらばらにやっていました。これではほんとう の意味での都市計画はできないというのが僕の持 論でしたから，駒沢公園においては土木・建築・ 造園が一緒になってやろうじゃないかともちかけ たわけです》(高山, 私信)。

マスタープランを担当した高山英華の回想である。 現在の駒沢公園は，誰もがスポーツを楽しむ総 合運動場として機能している（北井, 2008）。繁華 街にある代々木公園と比べ，駒沢では周囲が住宅
街であることから，子供から老人に至る年齢層， とくに犬を連れた人々の利用が多いのも特徵であ る（幸田, 2002）。

ちなみに，オリンピックの施設計画が行われて いたころ，高山英華 (都市計画), 丹下健三（都 市設計)，八十島義之助（交通計画）らを中心と して, 東京大学工学部では都市工学科の設立が検 討中であった。1962 年 4 月，わが国の大学にお ける最初の都市計画関係の学科として設立された 同学科は，その 2 年後すなわちオリンピック開 催の年, 駒場の教養課程から第 1 期の学生たち を迎える。東京オリンピックは, 都市計画の大学 教育の分野にも影響が広がっていったのである。

\section{3）オリンピックの成果と課題}

1964 年東京オリンピックによる東京都市計画 への成果をまとめると，以下となろう。

第一に，なかなか実現には至らなかった都市計 画案を一気呵成に完成させことがある。戦前から 計画されていた放射・環状道路，必要性が叫ばれ ていた首都高速道路，さらにはワシントン・ハイッ 返還に至るまで，オリンピックは長年にわたって残 されていた東京における都市計画の難問を解決し た。ここには土地買収の予算もさることながら，一 般市民たちの積極的協力も大きかったろう。関係 者たちの合意形成，行政手続き，土地買収，工事 で完成まで時間がかかりやすい基盤整備を，わず か数年のうちに完成させることはオリンピックな くして実現できなかった。

第二に，東京オリンピックは以前からあった計 画の実現だけでなく，現状の計画をよりよく「進 化」し，発展させる役目をも果たした。たとえば, ワシントン・ハイツは代々木公園となったし，駒沢 公園は現在のような総合運動場公園として結実し た。また，施設計画の実績は東京大学都市工学科 の開設にも発展していった。

しかし，東京オリンピックが逆に引き起こした 問題もある。

事業の拙速さは，環状 7 号線沿いの光化学入 モッグ発生や，日本橋川の景観破壊といった問題 を生みだした。これらは高度成長時代が反省期に さしかかる 20 世紀末から，あらわになってきて 
いる。オリンピックが終わって今や 50 年がたち, 首都高速道路の老朽化という事態はまさに待った なしの事態を迎えているのである。

\section{IV. 今後の東京計画と大規模イベント}

\section{1） 2 回の挫折}

1964 年のオリンピックののち, 東京では 2 度に わたって大規模イベントの開催が構想された。世 界都市博覧会（1996 年開催予定）と2016 オリ ンピック・パラリンピック招致である。だが，そ の両方とも実現に至らなかった。まずはその挫折 の経緯をみてみよう。

\section{1-1）世界都市博覽会}

世界都市博覧会の計画は 1988（昭和 63）年, 当時の鈴木俊一都知事が意欲を示し，諮問された 東京世界都市博覧会基本構想懇談会（座長・丹下 健三)が，会場を臨海副都心全域，会期を 1994(平 成 6) 年 $3 \sim 12$ 月（300 日間），入場者数目標を 3000 万人とし，都市の仕組みと営みを体験すると いう博覧会を提案して，「東京フロンティア」と命 名された（東京フロンティア協会，1996）。

1980 年代後半，日本はバブル経済の真っただ なかにあり，東京が世界都市化していくなかで, 横浜みなとみらい 21 , 千葉幕張新都心などの東 京湾ウォーターフロント都市開発が進行した。な かでも東京都の臨海副都心は，公共交通が整備さ れれば，都心とのアクセスからいって，もっとも 将来性のある地と考えられた。そこで東京を今後 ロンドン，ニューヨークなどと並ぶ「世界都市」 とする先導役として，博覧会が構想されたのであ る。当時，神戸，横浜，大阪，福岡など大都市臨 海部で次々と博覧会が開催され，東京臨海副都心 が出遅れた格好となっていた焦りもあったろう。

しかし，この遅れてきた博覧会計画は，1990 年代初頭のバブル崩壊の影響をまともに受けるこ ととなる。

東京都は計画を見直して開催を 2 年後の 1996 （平成 8）年に延長し，入場者目標も 2000 万人に 縮小，見学施設も恒常施設などを中心に改めた。 だが，1995（平成 7）年 4 月の都知事選の争点と なった末に，博覧会は当選した青島幸男新知事に
よる全面的中止という終焉を迎えることとなる。

博覧会の中止はバブル経済崩壊という事態での 当然の帰結だったといえよう。しかし，この中止 で一般都民が臨海副都心を訪れ，考える機会は残 念ながら失われた。青島知事は臨海副都心開発の 方針見直しの意向を示し，懇談会を公開としたも のの，1期のみで引退してしまったからである (進藤, 1998)。

\section{1-2） 2016 年オリンピック・パラリンピック 誘致}

博覧会が中止されて 10 年後，臨海部は再び大 規模イベントの場として構想される。

2005 (平成 17）年 8 月，当時の石原慎太郎都 知事が 2016（平成 28）年開催予定のオリンピッ ク・パラリンピック大会招致について発言，翌 2006 (平成 18) 年 3 月に東京都議会でオリンピッ ク招致が決議された（東京都, 2006）。

その後練られた計画では競技場の $90 \%$ を都心 の半径 $8 \mathrm{~km}$ 以内に配置することによって「史上 随一コンパクトなオリンピック」を目ざし，全 31 競技会場のうち，21 会場は既存施設を用いる プランとなった。このコンパクトなプランの中心 が臨海部であり，新設する 10 会場のうち，4 会 場の恒久施設，すなわちオリンピック・スタジア 厶，海の森水上競技場，若洲オリンピックマリー ナ，葛西臨海公園は，いずれも埋立地に建設予定 とされた（Tokyo 2016 Bid Committee, 2008)。

臨海部は 1940 年万国博覧会会場，1995 年世 界都市博覧会など，東京が大規模博覧会を開催す る候補地でありつづけてきたが，ついにオリン ピックの予定地にも想定されるようになったので ある。

この計画案により，東京都は 2008 (平成 20）年 6 月，四候補都市の 1 つに選出されたが，翌 2009 (平成 21）年 10 月のコペンハーゲン IOC 総会で の決選投票では第 3 位となり，当選したのはリオ デジャネイロだった。

リオデジャネイロの勝因は南米でそれまでオリ ンピックが開催されていなかったことが大きい が，市民の 8 割以上が開催を支持していることも 決め手の1つとなったといわれる。対して東京は, 
投票の前月に発表された評価委員会の報告書では 交通・インフラ・治安面で候補 4 都市中, 抜き んでた評価を得ていたものの，都民の支持率は $55.5 \%$ と最低だった。

つまり，2016オリンピック・パラリンピック 誘致計画は 10 年前の都市博覧会と同様，都民か ら多くの支持を集めることができぬまま，頓挫し たのである。

\section{2） 2020 東京オリンピック・パラリンピックヘ 向けて}

パリ，ロンドン，そして 1964 年の東京にみる ように，大規模イベントはいわば相互補完の関係 として, 都市計画の推進に貢献してきた。19 世 紀半ばから続けられたパリ改造が，ナポレオン III 世とオスマンが歴史の表舞台から退場した後 も，半世紀にわたって継続されたのは，約 10 年 に 1 度の割合で開催された万国博覧会によると ころが大きい。その博覧会において，最大の見せ 物はパリという都市そのものであり，時代が進む につれ，当初オスマンの計画にはなかった地下鉄 や建築物などが付け加えられて, 都市計画の成果 の上に芸術，ファッションが花開いていった。

1964 年夏季東京オリンピックは道路や公園な どの基盤整備を一気に完成させる効果をあげた。 明治以来，東京の都市計画はあまり進まず，関東 大震災, 戦災と 2 度にわたって焦土と化したと きの復興も不十分なままだったが，そんななか 1964 年のオリンピックは, 都市計画の遂行を妨 げている障害を吹き飛ばした。首都高速道路をは じめ東京の都市基盤は今もそのときの遺産に多く をよっている。

都市計画と大規模イベントの関係に注目する動 きはバブル時代にもあり（堺屋, 1984), 全盛期 には日本各地で博覧会開催という様相さえ呈し た。だが，バブルがはじけた後，イベントは徒花 で終わり，世界都市博覧会，2016 年オリンピッ クも挫折の已む無きに終わった。

これら状況を鑑みるとき，その挫折の背後に， 単なるバブル崩壊だけでなく，イベントの主要会 場とされた臨海副都心における都市計画の不明確 さという重要な欠陥を忘れてはならないだろう。
パリで万国博覧会が開催されたとき，オスマン の改造の必要性は市民たちに染く認識されてい た。1964 年東京オリンピックのときも戦災復興 を終え, 高度成長期へと進むなかで, 人口と産業 の集中・過密，交通問題などを何とかしなければ ならないという国民的合意があったからこそ，都 市計画も実現したのである。

2012 年ロンドンで行われたオリンピック・パラ リンピックも，ロンドン東部全体を再整備しなけ ればならないという市民の認識があったからこそ 支持された。それはオフィスと富裕層用住居を優 先し，ドックランズだけの開発を優先したサッ チャリズムへの反省からきたものだったのである。

対して, 世界都市博覧会, 2016 年オリンピッ ク・パラリンピックには，そうした国民あるいは 都民の支持があったろうか。半径 $8 \mathrm{~km}$ の円のな かにスポーツ施設をコンパクトに配したイベント 計画はよいとしても，臨海埋立地全体の計画自体 が都民の理解と支持を得るには，いまひとつの状 況だったといえるのではあるまいか。

バブル華やかなりし時代，東京湾岸の埋立地は 都市開発のフロンティアとして人々の夢を駆り立 てた。以来，横浜のみなとみらい 21 , 千葉の幕 張新都心はそれなりにできあがり，整備されてい るが，東京の埋立地開発にはなお不明の部分が数 多く残っている。そもそも中心となる臨海副都心 の名前自体が 13 号地, 東京テレポート, レイン ボータウン, お台場と, さまざまに変わり, どう いう「副都心」なのかもはっきりしていない。確 かに工事は進み, 新橋から「ゆりかもめ」に乗っ てみると, 車空から未来都市の風景が見え, 大手 民間デベロッパーによるオフィスや商業開発が進 んではいる。しかし，この商業開発地もアクトシ ティ, ダイバーシティ, パレットタウン, ワールド ヘッドクォーターなどと，デベロッパーごとに命 名されて混乱は収まりそうにない。はたして，こ の広大な埋立地全体が東京の都市計画でどう位置 づけられているのか, 東京の都市問題の解決にど ういう役割を果たすのか。そして東日本大震災で 判明したような避難, 津波, 液状化など防災問題 をどう解決するのか。それらを不明にしたまま, 
東京港の埋立地は明治以来およそ $6,000 \mathrm{ha}$, 実 に千代田区，中央区，港区，新宿区の 4 区をあ わせた規模にまで広がっているのである。

2013 (平成 25）年 9 月 7 日，アルゼンチンの ブエノスアイレスで開催された第 125 次 IOC 総会 で，東京は 2020 (平成 32）年夏季オリンピック・ パラリンピック開催地に決定した。ついに東京で 56 年ぶりに世界的イベント開催が行われることに なったのである。IOCに提出した計画によれば, スタジアムが現在の信濃町にある国立競技場の改 築になった点を除けば，晴海埋立地の選手村予定 地を中心に半径 $8 \mathrm{~km}$ 以内の臨海部に主要施設を 置く考え方は前回につくられた計画に準じている (東京 2020 オリンピック・パラリンピック招致 委員会, 2012)。

こうしたなかで行うべきは，オリンピック施設 の計画・建設とともに，臨海部埋立地の早急なマ スタープランづくりであろう。この土地は，今や 東京にとって，大規模イベント開催の場であると ともに，もはや残された数少ない資源なのだ。

1964 オリンピックの成果のなかで，駒沢公園 が優れていたのは，オリンピック後の敷地の使い 方を最初に議論し，計画したことであった。今回 もまず臨海部埋立地を, オリンピック・パラリン ピックという大規模イベント開催実施とともに, 東京の都市計画のなかでどう役立てていくかを議 論すべきだ。総合的視点からの臨海部埋立地マス タープランと，それによるオリンピック・パラリ ンピック後の跡地計画をつくってこそ，2020 東 京オリンピック・パラリンピックは，パリ都市改 造と並行して行われた万国博覧会や 1964 東京才 リンピックなどのように歴史に残り，都民に支持 された大規模イベントとして, 未来の東京の先導 役になることができるであろう。

都市計画は長期にわたる事業であり，市民の理 解がなければ継続されず，イベントも市民の支持 があってこそ盛り上がる。過去 10 余年間，臨海 部を会場とした計画案挫折を踏まえ，今こそ都市 計画とイベントを相互に関係させた総合的視点か らのオリンピック・パラリンピック計画を切に望 みたい。

\section{文献}

秋田茂 (2012): イギリス帝国史.中央公論社. [Akita, S. (2011): The History of the British Empire (Igirisu Teikokushi). Chuo Koronsha. (in Japanese) *]

東 秀紀 (2004):「サッチャリズムの都市計画」の特徴と 成果, 問題点の考察. 計量計画研究所. [Azuma, H. (2004): 'The Planning of Thatcherism': Its Implications, Results and Difficulties ('Satcharizumu No Toshi Keikaku' No Tokucho To Seika, Mondaiten). Institute of Behaviour of Science (in Japanese) *]

東 秀紀 (2010): 東京の都市計画家一高山英華。鹿島 出版会. [Azuma, H. (2010): A Planner of Tokyo: Prof. Eika Takayama (Tokyo No Toshi Keikakuka: Takayama Eika). Kajima Institute Publishing. (in Japanese) *]

馬場 健 (2007): イギリスにおける都市再開発を巡る 中央地方関係に関する調査報告一ロンドン・オリン ピック 2012 のためのドックランド再開発を例として. Clair レポート 184-4, 109-124. [Baba, K. (2007): A Report on the Relation between the central and local governments in the urban development in Britain. Clair Report 184-4, 109-124. (in Japanese $\left.)^{*}\right]$

藤森照信 (1982): 明治の東京計画. 岩波書店. [Fujimori, T. (1982): The Town Planning of Tokyo in the Meiji Era (Meiji No Tokyo Keikaku). Iwanami Shoten. (in Japanese) *]

Hall, P. (1988): Cities of Tomorrow. Wiley-Blackwell. 橋本一夫 (1994): 幻の東京オリンピック。日本放送出版 協会. [Hasimoto, K. (1994): The Unrealized Tokyo Olympic (Maboroshi No Tokyo Orinppiku). Nippon Broadcasting Publishing. (in Japanese)*]

石田頼房 (2004): 日本近現代都市計画の展開 18682003. 自治体研究社. [Ishida, Y. (2004): The Development of the Modern City Planning in Japan 1868-2003 (Nihon Kingendai Toshi Keikaku No Tenkai 1868-2003. Jichitai Kenkyusha. (in Japanese $\left.)^{*}\right]$

鹿島 茂 (1992): 絶景, パリ万国博覧会一サン・シモン の鉄と夢. 河出書房新社. [Kasima, S. (1992): Paris Exposition: The Iron and Dream of Saint-Simonism (Zekkei, Paris Bankoku Hakurankai: San-Shimon No Tetsu To Yume). Kawade Shobo Shinsha. (in Japanese ${ }^{*}$ ]

片木 篤 (2010): オリンピック・シティ東京. 河出書房 新社. [Katagi A. (2010): The Olympic City Tokyo (Olinppikku Shiti Tokyo).Kawade Shobo Shinsha. (in Japanese) *]

岸田日出刀 - 中山克己 - 高山英華 - 角田 栄 - 堀内享一 村田政真・浜口隆一 (1963) : 東京オリンピック施設 計画を展望する。新建築, 38(7), 610-612. [Kishida, H., Nakayama, K., Takayama, E., Tsunoda, S., Horiuchi, K., Murata, S. and Hamaguchi, R. (1963): The content of Tokyo Olympic 1964 fascilities. Shin-Kenchiku, 38(7), 610-612. (in Japanese) *] 
北井裕子（2008）: 東京建築物語. エイ出版社. [Kitai, H. (2008): A Story of Architectures in Tokyo (Tokyo Kenchiku Monogatari). Ei Publishing. (in Japanese)]

喜安 朗・川北 稔 (1986): 大都会の誕生一出来事の 歴史像を読む. 有斐閣. [Kiyan, R. and Kawakita, M. (1986): A Birth of Big Cities: A Historical Context of Incident (Daitokai No Tanjo: Dekigoto No Rekishizo Wo Yomu). Yuhikaku. (in Japanese)*]

幸田重行 (2002): 公園と動物一駒沢オリンピック公園 の事例。都市公園, 159, 73-77. [Kohda,S. (2002): A park and animals: An example of Komazawa Olympic Park. Public Park Magazine (Toshi Koen), 159, 73-77. (in Japanese) *]

越沢 明 (1991): 東京都市計画物語. 日本評論社. [Koshizawa, A. (1991): A Story of Urban Planning in Tokyo (Tokyo Toshi Keikaku Monogatari). Nihon Hyoronsha. (in Japanese)*]

尾崎一峰 (2002): スポーツ政策の形成に関する一研究 : オリンピック東京大会の選手村の選定過程を対象に. 一橋大学研究年報 ·人文科学研究, 39, 159-252.

[Ozaki, K. (2002): A study of the policy-making of sport: The process of the decision on the village of atheletes in Tokyo Olympics 1964. Hitotsubashi Research Series Humanities, 39, 159-252. (in Japanese with English abstract) ]

堺屋太一(1984): イベント・オリエンテッド・ポリシー 一楽しみの経済学. エヌジーエス。 [Sakaiya, T. (1984): Event Oriented Policy: Economics for Pleasure (Ibento Orienteddo Porishi Tanoshimi No Keizaigaku). NGS. (in Japanese)*]

進藤 兵 (1998): 「都市福祉国家」から「世界都市」へ II一東京都行政「改革」史序説 1975-1998. 名古屋 大学法政論集，176，1-66. [Shindo, H. (1998b): Urban welfare state to Global city: Politico-administrative/space/time governance in Tokyo metropolitan government 1975-1998. Journal of Law and Politics (Nagoya Daigaku Hosei Ronshu), 176, 1-66. (in Japanese with English abstract) ]

首都高速道路株式会社 (2013): 首都高速道路構造物の 大規模更新のあり方に関する調査研究委員会報告書.

[Metropolitan Expressway Co. Ltd. (2012): A Report of the Committee on the Big Scale Renovation of Facilities of the Metropolitan Expressway (Shuto Kosoku Doro Kozobutsu No Daikibo Koshin No Arikata Ni Kansuru Chosa Kenkyu Iinkai Hokokusho). (in Japanese) * ]

住田佳津夫 (2006): ロンドン市東部の再開発の動向. 建設経済研究所だより，212，2-8. [Sumida, K. (2006): The report of the redevelopment of the eastend in London. Construction Economy Report,
212, 2-8. (in Japanese)*]

高山英華・加藤 隆 (1964): オリンピック東京大会に おける施設計画。新建築， $\mathbf{3 9}(10), 118-123$. [Takayama, E. and Katoh, T. (1964): The planning of fascilities in Tokyo Olympic Games. Shin-Kenchiku, 39 (10), 118-123. (in Japanese) *]

丹下健三・藤森照信 (2002): 丹下健三. 新建築社. [Tange, K. and Fujimori, T. (2002): Kenzo Tange. Shinkenchikusha. (in Japanese with English abstract) *]

東京フロンティア協会編（1996): 世界都市博覧会一構 想から中止まで. 東京都. [The Association of Tokyo Frontier ed. (1996): The Great Exhibion of the World Cities: From Its Design to the Preventation (Sekai Toshi Hakurankai: Koso Kara Chushi Made). Tokyo City Government. (in Japanese)*]

Tokyo 2016 Bid Committee (2008): Tokyo 2016 application file.

東京 2020 オリンピック・パラリンピック招致委員会 (2012): 立候補ファイル. [Tokyo 2020 Bid Committee (2012): Discover Tomorrow: Tokyo 2020 Application file.]

東京市役所（1939）：第十二回オリンピック東京大会 東京市報告書. 東京市. [Tokyo City Government (1939): The Report on the Planning of the Twelfth Olympic Tokyo Games (Dai Junikai Orinpikku Tokyo Taikai Tokyo Houkokusho. Tokyo City. (in Japanese) *]

東京都 (2006): 東京オリンピック招致本部事業概要.

[Tokyo City Government (2006): The Outline of planning of the Invitation the 2016 Olypic Games (Tokyo Orinpikku Shochi Honbu Jigyo Gaiyo). (in Japanese)*]

山田正男 (1960): 欧州諸都市見聞記（下）。新都市, 14 (1), 31-32. [Yamada, M. (1960): A travel report of cities in Europe III. Shintoshi, 14(1), 31-32. (in Japanese) ]

山田正男 (2001): 東京の都市計画に携わって一元東京 都首都整備局長・山田正男氏に聞く，東京都新都市 建設公社まちづくり支援センター。 [Yamada, M. (2001): My Memory of the Urban Planning in Tokyo: Interview with Mr.Masao Yamada, the Former Head of the Metropolitan Planning Bureau of Tokyo City Government (Tokyo No Toshi Keikaku Ni Tazusawatte: Moto Tokyoto Shuto Seibi Kyokucho Yamada Masao Shi Ni Kiku). The Supporting Centre for the Community Development, New City Development Corporation, Tokyo City Government. (in Japanese) *]

${ }^{*}$ Title etc. translated by H.A. 